\title{
Hydrological characterization of the Araguaia River through reference flows
}

\author{
Rodolfo Rosario Klautau de Araujo Gomes ${ }^{1}$ (D) $\cdot$ Lindemberg Lima Fernandes ${ }^{2}$
}

Received: 20 August 2017/Accepted: 11 September 2017/Published online: 19 September 2017

(c) The Author(s) 2017. This article is an open access publication

\begin{abstract}
This study examined the hydrological behavior of the Araguaia River through reference flow, analyzing the capacity of granting the river segments in three different fluviometric stations. The study exposed the comparison of monthly and annual reference flow, considering a hydrological series of 33 years. Consequently, it was proposed seasonal flow comparing to the methodology of annual reference flow for water grants in national rivers. The adoption of the annual reference flow restricts the grants of water use in most of the time, because the proposal of monthly and seasonal $Q_{95 \%}$ in the rainy period for grants processes showed much higher values. The proposal of monthly and seasonal reference flows to grant the multiple right of use of water may be the most adequate for power generation, because it presents the inherent characteristics of the flows of each month and per period, respectively. However, the use of seasonality for grants must be analyzed along with the environmental aspect of the river basin concerning to the damage of aquatic life of the Araguaia River.
\end{abstract}

Keywords Fluviometric station - Reference flow - Grant · Araguaia River

Rodolfo Rosario Klautau de Araujo Gomes

rodolfoklautaugomes@gmail.com

Lindemberg Lima Fernandes

linlimfer@gmail.com

1 Environmental and Sanitary Engineering, Universidade Federal do Pará, Belém, Brazil

2 Sustainable development in the humid tropics, Universidade Federal do Pará, Rua Augusto Corrêa 01, Guamá, Belém, Brazil

\section{Introduction}

Brazil has a privileged situation regarding its water availability compared to other countries, but there are problems of water scarcity in the country, which are fundamentally due to the combination of the exaggerated growth of localized demands and the degradation of water quality (Setti et al. 2001).

The great need for multiple uses of water due to its huge demand in urban areas, industry, agriculture and power generation justifies the necessity to increase the efficiency of water management and, therefore, it requires reforms in the planning of the water resources use (Montaño and Souza 2016).

Law 9.433/97, which establishes the National Water Resources Policy (PNRH) and creates the National Water Resources Management System (SNGRH), seeks to organize planning and management of water resources at a national level. Therefore, the granting of rights to use water resources, which is one of the PNRH instruments, aims to ensure the quantitative and qualitative control of water uses and the effective exercise of water access rights (Brasil 1997).

To obtain more concrete results to meet all usage demands, it is necessary to know the fluvial behavior of watershed, using the reference flow methodology. According to Silva et al. (2006), the reference flow is the establishment of a flow rate that becomes the maximum limit of water use in stream. Therefore, there are different standards for adoption of reference flows in Brazil, and the variability of these standards is related to the individual characteristics of each river basin.

According to Mendes (2007), the minimum flows such as $Q_{7,10}$ and the permanence flow rates $Q_{90 \%}$ and $Q_{95 \%}$ are generally used as reference flows. Brazil and its federal

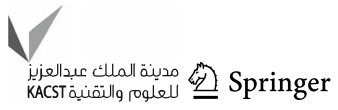


states set their own percentages of the reference flow as the maximum flow for consultative uses.

The fluvial behavior undergoes variations throughout the year, in which they are closely related to the precipitation. In most of Brazil, there is a marked seasonality with rainy seasons and well-defined droughts, so that at the end of the dry period one can observe flow rates far below the average flow rate and even absence of water (ANA 2016).

The Araguaia River forms the natural landmark initially between the states of Mato Grosso (MT) and Goiás (GO), and then between Mato Grosso and Tocantins (TO) and finally between Pará (PA) and Tocantins. According to the Agência Nacional de Águas (ANA), the river is therefore classified as a national river, which divides or passes through two or more states or even crosses the border between Brazil and another country. Therefore, it is incumbent upon ANA to issue the right to use of water resource in the Araguaia River for several types of uses, thus defining the maximum flow rate to be granted.

Therefore, the aim of the study is to evaluate the hydrological behavior of the Araguaia River through temporal variability, analyzing the concession capacity of the river segments, divided into upper, medium and lower Araguaia. Different standards were defined to calculate reference flows through monthly, seasonal and annual analyses.

\section{Materials and methods}

\section{Area of study}

The Tocantins-Araguaia basin is the fourth largest drainage basin in South America, extending over approximately $800,000 \mathrm{~km}^{2}$ and encompassing a part of two large South American biomes: Amazon forest in the north and Brazilian Savanna (Cerrado) in the south. It is formed mainly by two major river systems: Tocantins and Araguaia (Aquino et al. 2005, 2009).

The Araguaia River is a plain river that rises in the foothills of the Serra dos Caiapós at $850 \mathrm{~m}$, traveling almost parallel to the Tocantins for about $2600 \mathrm{~km}$. Four sections are formed in the cascade, with the gradient around 300-200 $\mathrm{m}$ in the middle course and below $100 \mathrm{~m}$ in the lower course. The upper course is $450 \mathrm{~km}$ long on a steep gradient of $120 \mathrm{~cm} / \mathrm{km}$, with waterfalls and rapids. The Island of Bananal, considered the largest fluvial island in the world (Mérona et al. 2010), is located in the uppermiddle course.

The climatic conditions that predominate at the Araguaia River basin are of continental tropical nature, due to its continental position that does not suffer the direct effect of the intertropical confluence. According to Koppen, this region is classified into type Aw, hot and humid climate, with annual rainfall of the order of $1700 \mathrm{~mm}$, average monthly temperatures oscillating between 24 and $26^{\circ} \mathrm{C}$ and drought in the June-September period (ANA 2009).

According to Latrubesse and Stevaux (2002), the Araguaia River is divided into three segments: upper, middle and lower Araguaia, as shown in Fig. 1. The upper Araguaia (Upper-ARA) drains an area of $36,400 \mathrm{~km}^{2}$. In the middle Araguaia (Middle-ARA) that extends for $1600 \mathrm{~km}$ from Registro do Araguaia to Conceição do Araguaia, the drainage area increases dramatically, reaching an area greater than $300,000 \mathrm{~km}^{2}$. The lower Araguaia (LowerARA) constitutes the locality of Conception of the Araguaia until its confluence with the Tocantins River.

The selected fluviometric stations for the study, presented in Table 1, were chosen so that they could relate the flow behavior at three segments along the Araguaia River. Therefore, a station near the downstream of upper, middle and lower Araguaia was selected.

Flow data of fluviometric stations were obtained on ANA's Hidroweb database during the period from 1975 to 2011. In 1985, there were faults at the Araguatins station that were corrected using the simple linear regression method proposed by Tucci (2002). The Conceição do Araguaia station had a good data series, but there were faults in 1980, 1987 and 2008. The Araguatins and Aruanã stations had gaps in 1980, 1987 and 2006 that could not be filled because of having large series with failures in consecutive months. Therefore, the 1980s, 1987s, 2006s and 2008s were discarded in all fluviometric stations to homogenize the historical series of the study. Thus, a historical series of the study had 12,052 daily flow records in 33 years.

\section{Low flow $Q_{7,10}$}

According to Oliveira (2008), the low flows are naturally linked to the critical periods of the river; so it is essential to know the flow rate for studies of water availability. The low flow $Q_{7,10}$ method analyses drought flow which occurs for a period of seven consecutive days at a period in 10 years. Therefore, it is examined 365 daily average flows by the database of daily flows, calculating the moving average of seven consecutive days $\left(Q_{7}\right)$, in which it is calculated for seven terms that are moving (average from the 1 st to the 7 th day, from the 2 nd to 8 th day, from the 3rd to 9th day), and so on.

Statistical analyses were performed using values of the lowest average of 7 days of each year, which when extrapolated provided the value for different times of return. Therefore, we set out for the frequency analysis and the determination of the flow rate for the desired return period. 


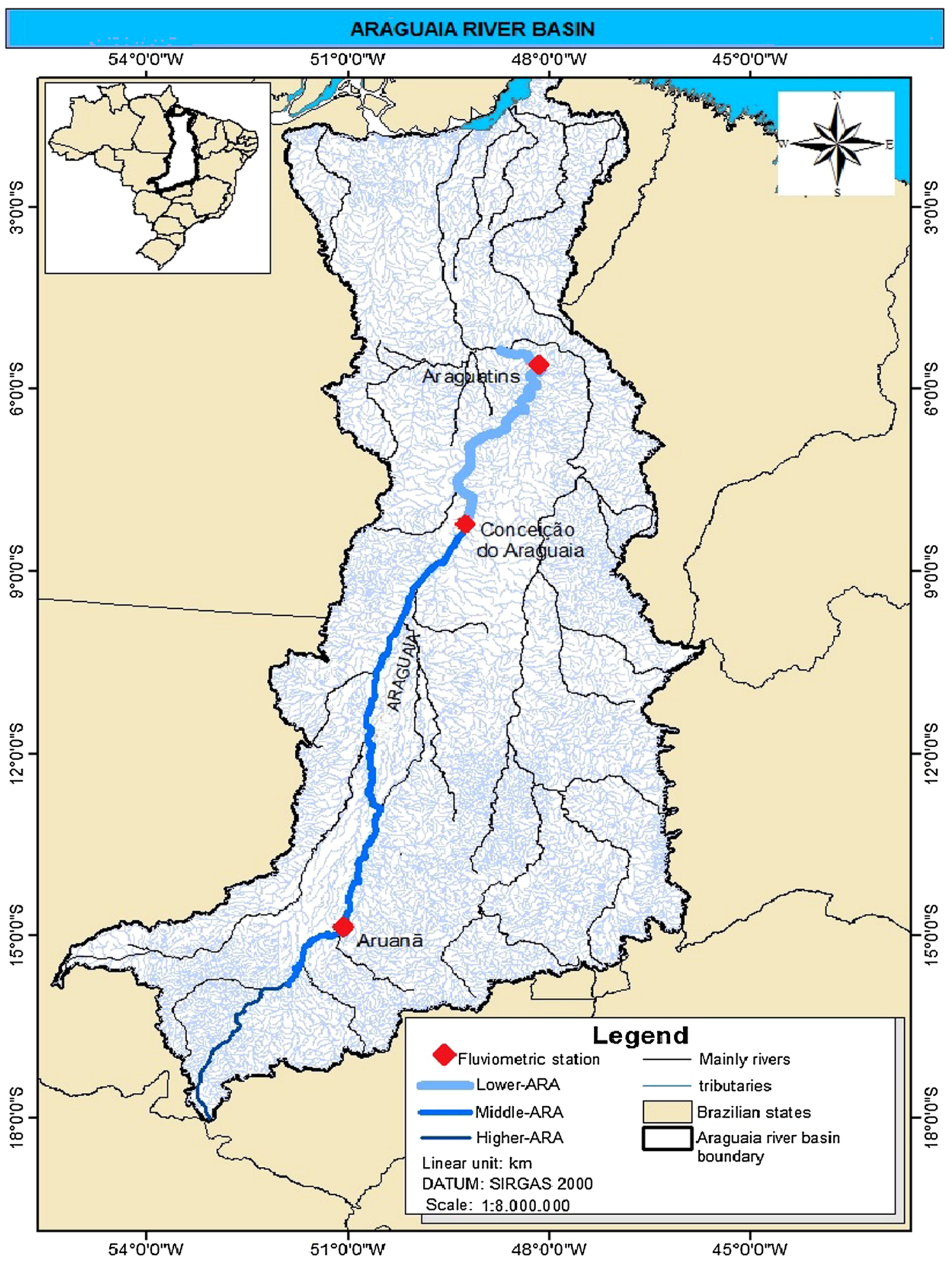

Fig. 1 Location of the Araguaia River basin

In the present study, the lognormal distribution function was applied following the methodology presented by Chow et al. (1988) and Von Sperling (2007), which corresponds to the adjustment of a normal distribution to the logarithms $\left(\log _{10}\right)$ of the flows through Eq. (1) and the calculation of flow $Q$ in $\mathrm{m}^{3} / \mathrm{s}$ by converting the value of the logarithm of the flow to the flow itself through Eq. (2) as 
Table 1 Selected fluviometric stations at Araguaia River. Source: Adapted Hidroweb-ANA, 2016

\begin{tabular}{|c|c|c|c|c|}
\hline Station code & Station & Drainage area $\left(\mathrm{km}^{2}\right)$ & Latitude & Longitude \\
\hline 25200000 & Aruanã-GO & 76,300 & $-14: 54: 46$ & $-51: 04: 53$ \\
\hline 27500000 & Conceição do Araguaia-PA & 332,000 & $-08: 16: 10$ & $-49: 15: 34$ \\
\hline 28850000 & Araguatins-TO & 388,000 & $-05: 39: 05$ & $-48: 07: 57$ \\
\hline
\end{tabular}

$\log _{10}\left(Q_{\text {calculated }}\right)=$ mean of $\log _{10}(Q)+Z$ $\times$ standard deviation of $\log _{10}(Q)$,

$Q_{\text {calculated }}=10^{\log _{10}\left(Q_{\text {calculated }}\right)}$,

where $Z$ is the variable of standardized normal distribution, which returns the standardized normal ordered value associated with a certain cumulative probability. An interpolation was performed to obtain the value of the flow corresponding to the return period of 10 years for each fluviometric station.

\section{Permanence flow $Q_{90 \%}$ and $Q_{95 \%}$}

The permanence flows are obtained by permanence curves that relate the flow with the percentage of the time in which it is equalized or exceeded; $Q_{90}$ and $Q_{95}$ are frequently applied by the Brazilian legislation (Mendes 2007). The $Q_{90}$ is the flow with $90 \%$ permanence in time and $Q_{95}$ with $95 \%$, with an extrapolation in the rainy periods in which there is a great increase of the river flow.

The calculation of $Q_{90 \%}$ and $Q_{95 \%}$ permanence flows was carried out using a historical series of daily values, taking the same years as those used in the calculation of $Q_{7,10}$. The calculations were carried out in a spreadsheet, according to the methodology proposed by Von Sperling (2007).

The permanence curve is usually estimated, considering the entire data period of the historical series. This type of curve does not contemplate the effects of seasonality throughout the year and of the interannual variation. To consider the seasonality, it can determine the curve for each month of the year for all the years of the series. Therefore, this type of result allows to distinguish the monthly conditioning factors of seasonality (Cruz and Tucci 2008).

The studies on granting criteria by Ribeiro $(2000,2003)$ considered empirical monthly and seasonal empirical flows through simulations, comparing the use of a single annual value. This methodology was also used by Vergara et al. (2013), comparing the reference flow $Q_{90 \%}$ monthly, bimonthly and quarterly with $Q_{90 \%}$ seasonally, by the environmental agency of the state of Tocantins.

In this way, the calculation of the monthly and seasonal permanence flows was also performed, in which 12 values of $Q_{90 \%}$ and $Q_{95 \%}$ permanence flows were obtained for the monthly analysis and a value of $Q_{90 \%}$ and $Q_{95 \%}$ for the rainy season and for the drought season.

\section{Maximum grant flow}

The maximum granted flow ( $\left.Q_{\text {max } \_ \text {granted }}\right)$ is the maximum available flow to be granted for various uses. According to Mendes (2007), Brazil and its federal states express the maximum limit as percentages of a reference flow when establishing the water availability for granting for consultative uses as in Eq. (3):

$Q_{\text {max _granted }}=k * Q_{\text {Ref }}, 0<k<1$,

where $Q_{\text {Ref }}$ is the determined reference flow $\left(\mathrm{m}^{3} / \mathrm{s}\right)$ and $k$ is the maximum withdrawn percentage for grant, expressed by a determined multiplicative factor.

The determined criterion for granting rivers in the domain of the Federal Government by ANA is that the granting flow must be up to $70 \%$ of $Q_{95 \%}$ and may vary according to the peculiarities of each region (ANA 2011). Therefore, the value of $k$ will be 0.70 for this situation. Following the methodology of Cruz (2001), it was possible to evaluate the maximum flow rate, by performing seasonal and annual analysis.

\section{Results and discussion}

The flow behavior is directly related to the rainfall regime, as well as the use and occupation of the soil and physical properties of the river basin. Discharge changes over time are represented by a hydrograph of each station analyzed and provide an idea of the temporal variability of annual periodicities of dry and rainy seasons, as shown in Fig. 2.

The hydrographs for the fluviometric stations comprised average daily flows, reflecting peaks of maximum and minimum flows and clearly showing the oscillation of the hydrological regime of the system.

It is observed that the three higher maximum flows of the considered period occurred in 1979, 1997 and 2004 for the three fluviometric stations. The 1976s, 1996s, 1998s and 1999s presented lower flows than the double of 
Fig. 2 Hydrograph of the average daily discharge of each fluviometric station from 1975 to 2011
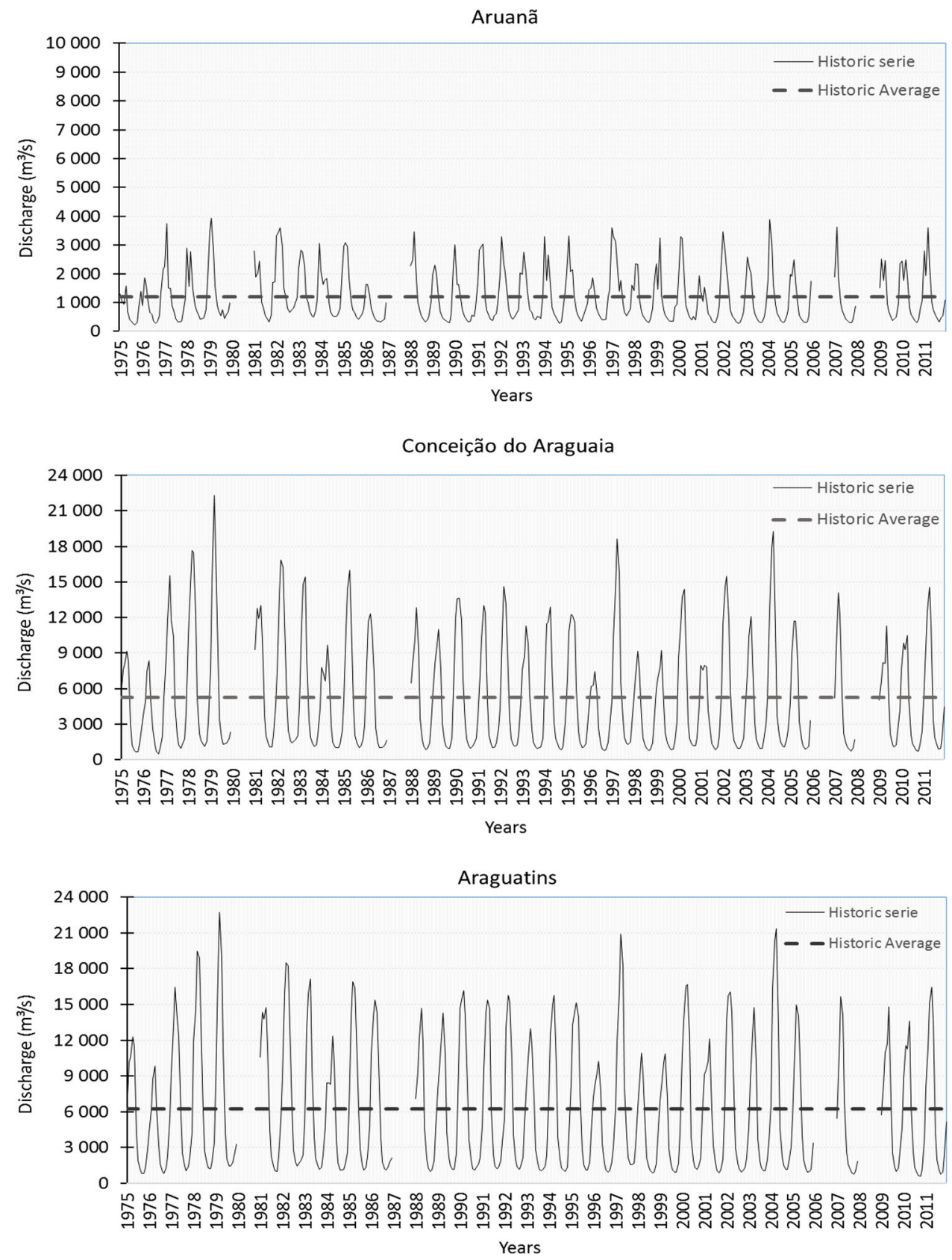

historical average flow at Araguatins station. However, these same years and 2001s presented flows close to the historical average in the Conceição do Araguaia station, according to Fig. 2b, c. As can be shown in Fig. 2a, there was a variability in the Aruanã station, in which only the 1975s, 1976s, 1986s, 1996s and 2001s were expressively the driest years.

Another fact that can be noticed in Fig. 2 is the upward trend in flow as the drainage area increases from upstream to downstream of the Araguaia River. The drainage area of Aruanã $\left(76,300 \mathrm{~km}^{2}\right)$ is much lower than those of Araguatins $\left(388,000 \mathrm{~km}^{2}\right)$ and Conceição do Araguaia $\left(332,000 \mathrm{~km}^{2}\right)$.
The discharge peaks of Araguaia River occur predominantly from January to May; however, in the region near higher Araguaia, there are variabilities and additions in the peaks that begin in December. The lowest discharges are from July to October for all selected stations, according to Fig. 3.

Observing Fig. 3b, c, the highest peaks usually occur from January to April at the Conceição do Araguaia and Araguatins stations. The peaks at Aruanã station occur from January to March, according to Fig. 3a, linking directly the hydrologic regime with the climate of upper Araguaia region. This region is already part of the Cerrado 
Aruanã

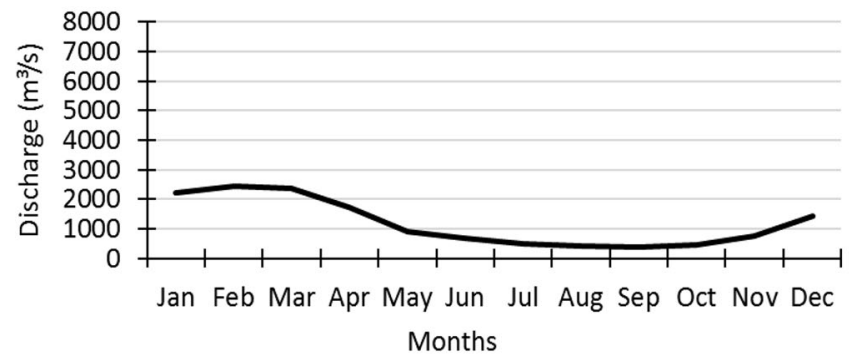

Conceição do Araguaia

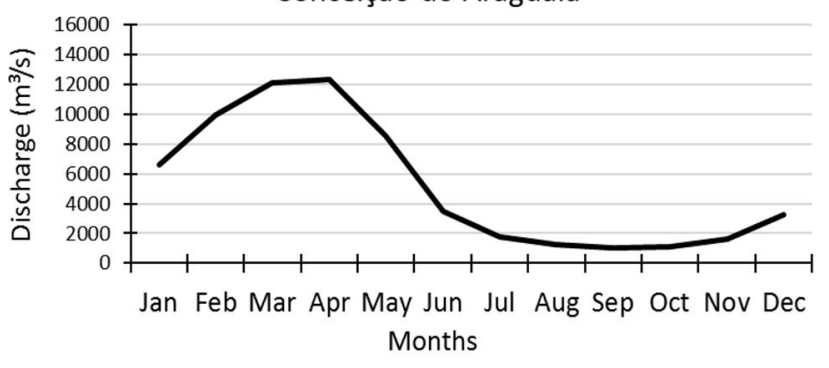

Araguatins

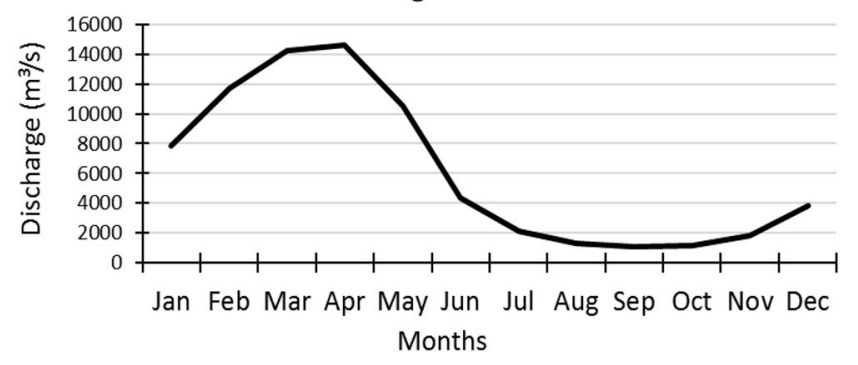

Fig. 3 Hydrograph of the average monthly discharge of each fluviometric station from 1975 to 2011

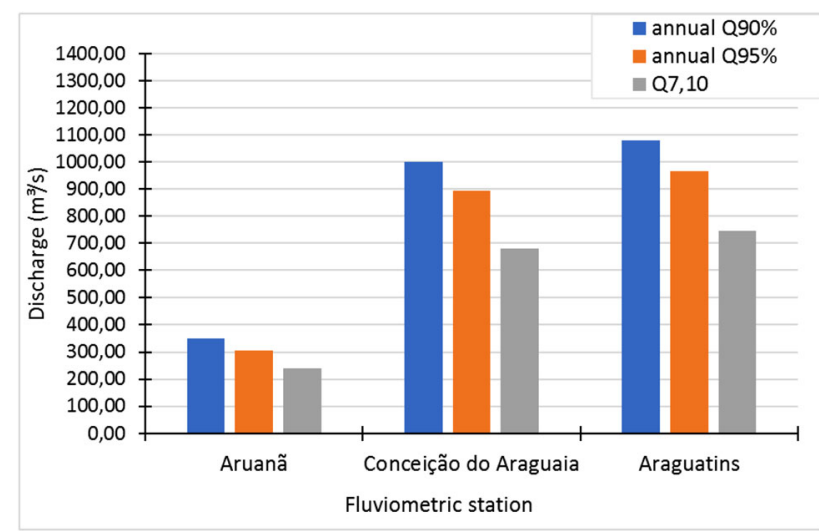

Fig. 4 Annual reference flows $Q_{90 \%}, Q_{95 \%}$ and $Q_{7,10}$ for the period from 1975 to 2011

biome, characterized by having two well-defined seasons, rainy season and drought season, while the other stations further downstream are in the Amazon biome.

In Fig. 4 , it is observed that the flow $Q_{7,10}$ is more restrictive and has lower values than the annual $Q_{90 \%}$ and $Q_{95 \%}$ for each fluviometric station.

According to Castro et al. (2004), when the water demand is high in the watershed, the practice of applying a more restrictive limit may make it impossible to grant an adequate concession for surface water catchment for the existing demands in the region, leading to conflictive situations. The flow rate $Q_{7,10}$ is required when verifying the self-purification capacity of a river to get effluents under more unfavorable conditions.
When it establishes the permanence flows per fluviometric station, there is a great difference among the $Q_{90 \%}$ and $Q_{95 \%}$ obtained by annual test compared to the permanence flows in the monthly tests, as can be observed in Fig. 5.

The values of $Q_{90 \%}$ and $Q_{95 \%}$ per month have shown a greater capacity of granting from December to June, against the annual $Q_{90 \%}$ and $Q_{95 \%}$. From August to October, the monthly permanence flows are close to the annual $Q_{90 \%}$ and $Q_{95 \%}$. Therefore, Ribeiro $(2000,2003)$ and Vergara et al. (2013), recommended the adoption of monthly permanence flows, since it obtains better results than the use of a single annual value.

The socioeconomic options and goals must be considered as well as the multiple uses in addition to purely hydrological criteria, when evaluating the granting flow. Figures 6, 7 and 8 show the seasonal $Q_{95 \%}$ for the four wettest months (from January to April) and the four driest months (from July to October).

The $Q_{95 \%}$ for the drought season against the annual $Q_{95 \%}$ showed similar flow values. The extrapolation of $Q_{95 \%}$ for the rainy season becomes more expressive at the stations closest to downstream of the Araguaia River, as can be observed in Figs. 7 and 8 .

The use of annual $Q_{95 \%}$ restricts the granting of concession to users because it does not consider the rainy and drought period of the region. Therefore, it may be more appropriate to define the percentage to be withdrawn for granting the $Q_{95 \%}$ seasonal flow, considering the higher and lower flows, according to Table 2 . 
Fig. 5 Monthly reference flows $Q_{90 \%}$ and $Q_{95} \%$ for each fluviometric station for the period from 1975 to 2011
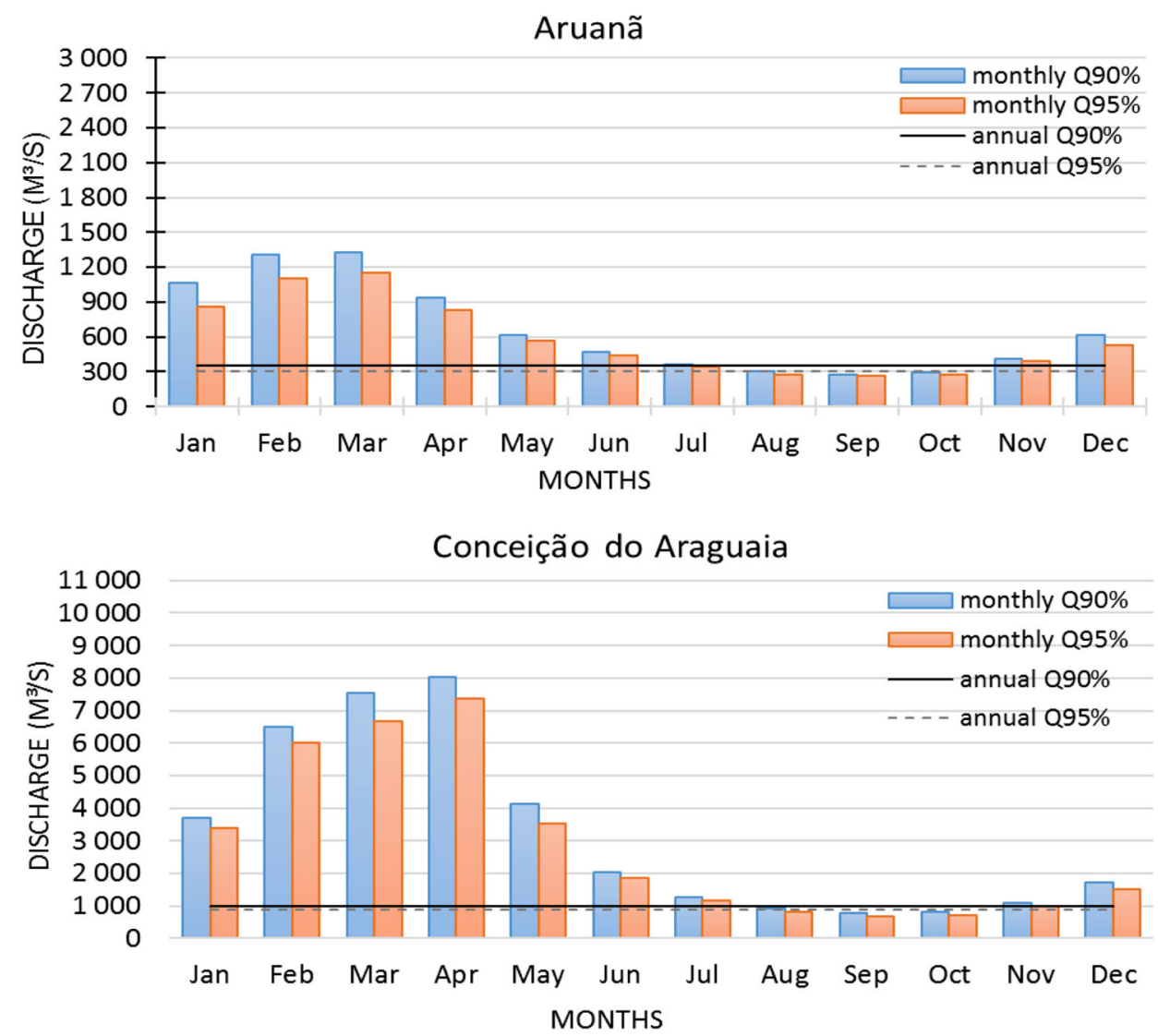

Araguatins

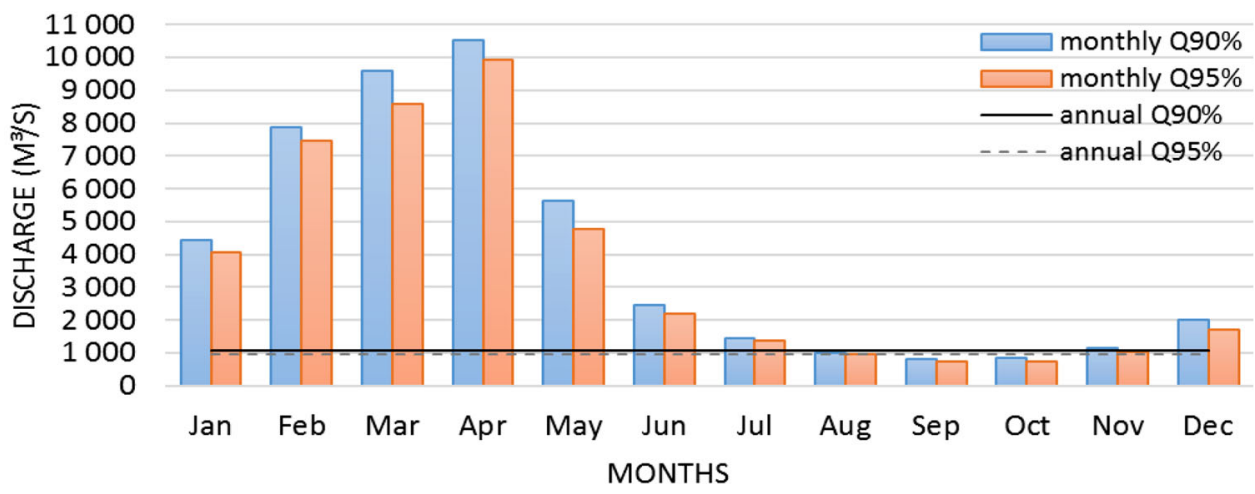

It can be observed that the $Q_{\text {max } \_ \text {granted }}$ for the drought season presented a value close to the single annual $Q_{\text {max_granted }}$ in three studied stations. However, the difference between the annual and seasonal $Q_{\text {max_granted }}$ in the rainy season is more significant in Conceição do Araguaia and Araguatins with values greater than $1000 \mathrm{~m}^{3} / \mathrm{s}$. Therefore, the maximum granted flow for a single annual $Q_{95 \%}$ is more restrictive, since it does not consider the high granting capacities in the rainy season and, consequently, the flow to be granted for each user will be lower.

In fact, the criterion of the seasonality for granting favors the right of use for power generation. However, this criterion must be analyzed concomitantly with the environmental aspects of the river basin, since the indiscriminate use of the water resource can lead to water stress and damage to aquatic life. Thus, the greater amount of granted flow induces a greater exploration of the aquatic environment.

\section{Conclusion}

The hydrological characterization through reference flows is utilized for the process of analysis of the river regime of the Araguaia River, which allows obtaining data of 


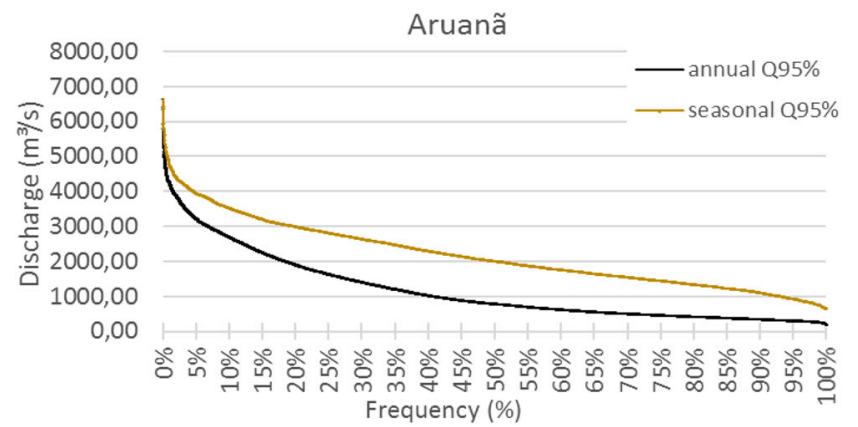

(a)

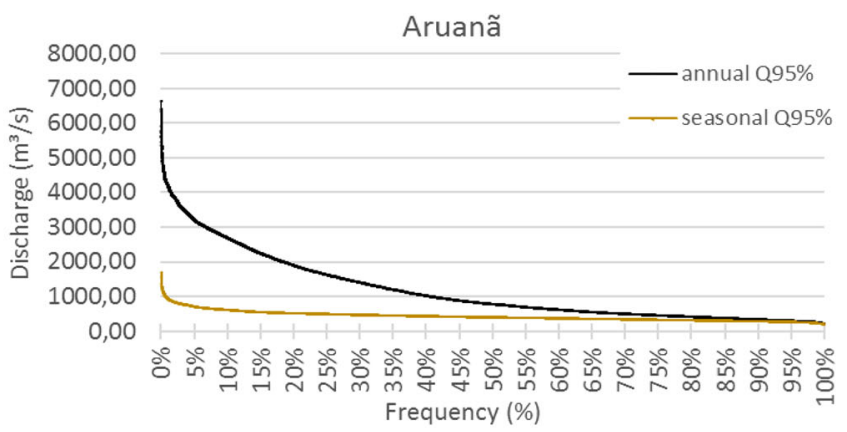

(b)

Fig. 6 Comparison of annual and seasonal permanence flow in Aruanã: a permanence curve in the rainy season; b permanence curve in the drought season

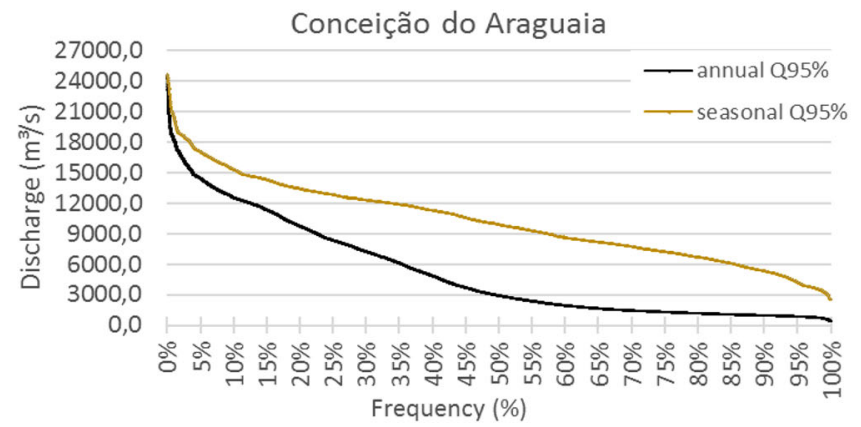

(a)

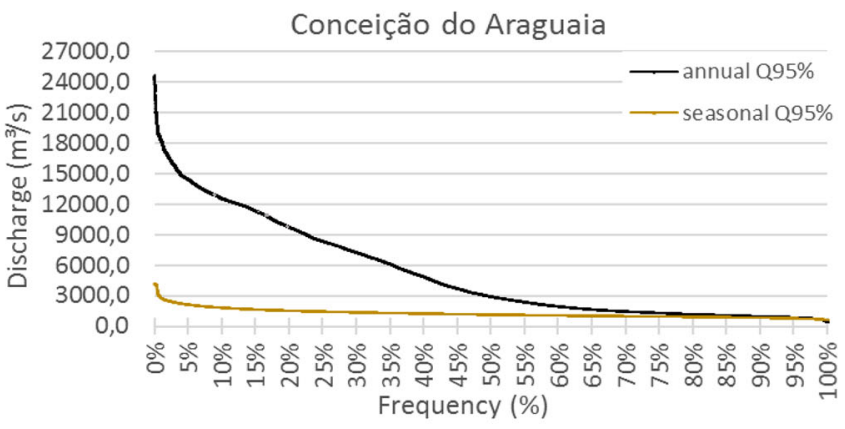

(b)

Fig. 7 Comparison of annual and seasonal permanence flow in Conceição do Araguaia: a permanence curve in the rainy season; b permanence curve in the drought season

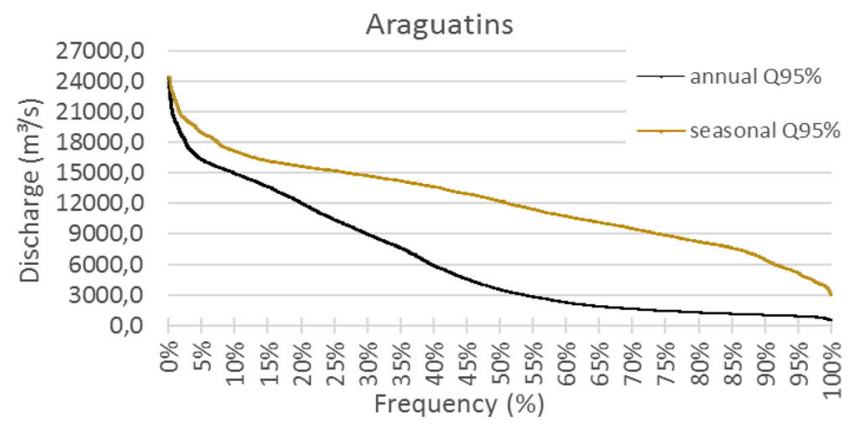

(a)

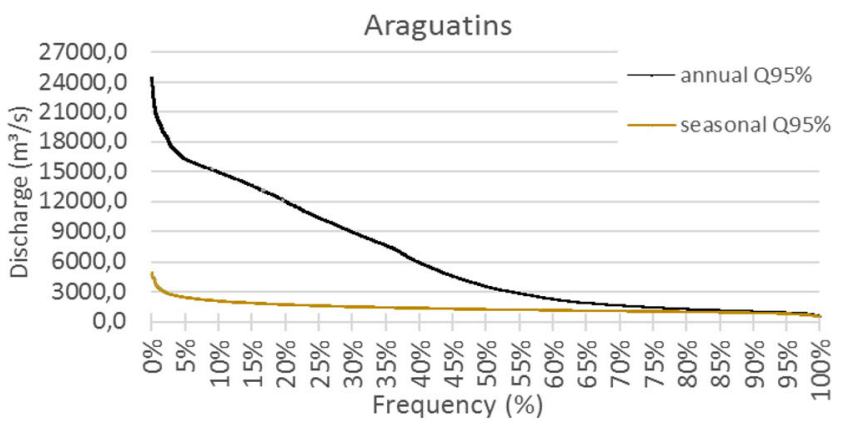

(b)

Fig. 8 Comparison of annual and seasonal permanence flow in Araguatins: a permanence curve in the rainy season; $\mathbf{b}$ permanence curve in the drought season

significant importance for the planning of water resources, applying them to the granting of environmental licenses articulately. This articulation allows to evaluate the enterprises in all its phases regarding its environmental aspect and the water availability.

However, when analyzing the reference flows, we observed the variability in the region near upstream and downstream of the Araguaia River. In general, the values of flows increase when there is an increase of the drainage area and, consequently, makes possible an evaluation for risks of floods in future works.

It was observed that the adoption of the annual reference flow restricted the grants of water use most of the time, since the proposal of monthly and seasonal $Q_{95 \%}$ in the rainy period for the granting processes presented values much higher. This significant restriction can influence the regional economy. It was also verified that the river has a greater capacity of granting, mainly from February to April 
Table 2 Comparison of annual and seasonal reference flows and their respective maximum grant flow from each fluviometric station in the period from 1975 to 2011

\begin{tabular}{|c|c|c|c|c|c|c|}
\hline \multirow[t]{2}{*}{ Fluviometric station } & \multicolumn{2}{|c|}{ Annual permanence flow $\left(\mathrm{m}^{3} / \mathrm{s}\right)$} & \multicolumn{4}{|c|}{ Seasonal permanence flow $\left(\mathrm{m}^{3} / \mathrm{s}\right)$} \\
\hline & $\begin{array}{l}\text { Annual } \\
Q_{95 \%}\end{array}$ & $Q_{\text {max_granted }}$ & $\begin{array}{l}Q_{95 \%} \\
\text { (rainy season) }\end{array}$ & $\begin{array}{l}Q_{\text {max_granted }} \\
\text { (rainy season) }\end{array}$ & $\begin{array}{l}Q_{95 \%} \\
\text { (drought season) }\end{array}$ & $\begin{array}{l}Q_{\text {max_granted }} \\
\text { (drought season) }\end{array}$ \\
\hline Aruanã & 306.14 & 214.30 & 938.59 & 657.01 & 275.97 & 193.18 \\
\hline $\begin{array}{l}\text { Conceição do } \\
\text { Araguaia }\end{array}$ & 892.78 & 624.95 & 4245.24 & 2971.67 & 765.28 & 535.70 \\
\hline Araguatins & 965.02 & 675.51 & 5238.17 & 3666.72 & 823.47 & 576.43 \\
\hline
\end{tabular}

for Araguatins and Conceição do Araguaia stations, and from January to March for the Aruanã station.

Therefore, the ways of analyzing the reference flows influence the grants: between a state and another one, and from these to the Federal Government. The proposal of monthly and seasonal reference flows to grant the multiple right of water use may be the most adequate for power generation, since it presents the inherent characteristics of the flows of each month and per period, respectively. However, the use of seasonality for grants should be analyzed along with the environmental aspects of the river basin as well as the impact on aquatic life.

Open Access This article is distributed under the terms of the Creative Commons Attribution 4.0 International License (http:// creativecommons.org/licenses/by/4.0/), which permits unrestricted use, distribution, and reproduction in any medium, provided you give appropriate credit to the original author(s) and the source, provide a link to the Creative Commons license, and indicate if changes were made.

\section{References}

ANA, Agência Nacional de Águas. (2009) Plano estratégico de Recursos Hídricos da Bacia Hidrográfica dos rios Tocantins e Araguaia: relatório síntese. (Strategic Plan for Water Resources of the Tocantins and Araguaia River Basins: synthesis report). SPP, Brasília, p 256

ANA, Agência Nacional de Águas. (2011) Outorga de direito de uso de Recursos Hídricos. Caderno de Capacitação de Recursos Hídricos. (Grant of right of use of Water Resources. Water Resources Training Notebook.), vol 6. SAG, Brasília-DF, p 50

ANA, Agência Nacional de Águas. (2016) Conjuntura dos Recursos Hídricos no Brasil: Informe 2016. (Conjuncture of Water Resources in Brazil: Report 2016.) Superintendência de Planejamento de Recursos Hídricos (SPR) Brasília-DF

Aquino S, Stevaux JC, Latrubesse EM (2005) Regime Hidrológico e Aspectos do Comportamento Morfohidráulico do Rio Araguaia. (Hydrological regime and aspects of morfohydraulic behavior of the Araguaia river). Revista Brasileira de Geomorfologia. Year 6 , no. 2

Aquino S, Stevaux JC, Souza Filho EE (2009) Caracterização hidrológica e geomorfológica dos afluentes da bacia do rio Araguaia (Hydrological and geomorphological characterization of tributaries of the Araguaia river basin). Revista Brasileira de Geomorfologia 10(1):43-54
BRASIL. Lei $\mathrm{N}^{\circ}$ 9.433, de 8 de janeiro de 1997-Política Nacional de Recursos Hídricos (PNRH). (Law No. 9,433, January 8th, 1997-National Policy of Water Resources) Casa Civil. Presidência da República. Brasília

Castro LMA, Diniz MGM, Silva AG (2004) Aplicação do Instrumento da Outorga no Gerenciamento dos Recursos Hídricos em Minas Gerais: A Bacia do Ribeirão Entre Ribeiros. (Application of the Granting Instrument for the Management of Water Resources in Minas Gerais: The Ribeirão Basin among Ribeiros). In: SIMPÓSIO DE RECURSOS HÍDRICOS DO NORDESTE, 7. Anais. São Luís: ABRH

Chow VT, Maidment DR, Mays LW (1988) Applied hydrology. McGraw-Hill, Maidenheach, p 572

Cruz JC (2001) Disponibilidade hídrica para outorga: avaliação de aspectos técnicos e conceituais. (Water availability for granting: evaluation of technical and conceptual aspects.) p 199. In: PhD thesis in Engineering-Instituto de Pesquisas Hidráulicas, Universidade Federal do Rio Grande do Sul, Porto Alegre; Brazil

Cruz JC, Tucci CEM (2008) Estimativa da disponibilidade hídrica através da curva de permanência. (Avaliation of water availability through the permanence curve.) Revista Brasileira de Recursos Hídricos. Porto Alegre 13:111-124

de Mérona B, Juras AA, dos Santos GM, Cintra IHA (2010) Os peixes e a pesca no baixo Rio Tocantins: vinte anos depois da UHE Tucuruí. (Fishers and fishing in the lower Tocantins river: twenty years after the Tucuruí HPP). Centrais Elétricas do Norte do Brasil S.A-Eletrobras Eletronorte, p 208

Latrubesse E, Stevaux JC (2002) Geomorphology and environmental aspects of Araguaia Fluvial Basin, Brazil. In: Z. Geomorphologie. Berlim: Suppl.-Bd. 129, pp 109-127

Mendes LA (2007) Análise dos critérios de outorga de direito de usos consuntivos dos recursos hídricos baseados em vazões mínimas e em vazões de permanência. (Analysis of grant criteria based on minimum flow according to duration curve for water consumptive uses). São Paulo, p 189. In: Master thesis in Water Resources. Escola Politécnica da Universidade de São Paulo, Brazil

Montaño M, Souza MP (2016) Integração entre planejamento do uso do solo e de recursos hídricos: a disponibilidade hídrica como critério para a localização de empreendimentos. (Coupling landuse and water resources planning: water availability as a locational criterion). Eng Sanit Ambient 21(3):489-495

Oliveira FA (2008) Procedimentos para aprimorar a regionalização de vazões: estudo de casos da Bacia do Rio Grande. (Procedures to improve the hydrologic regionalization: study of Rio Grande's basin.) Master thesis in Water Resources. Universidade Federal de Viçosa. Viçosa-MG, p 106

Ribeiro MMR (2000) Alternativas para Outorga e a Cobrança pelo Uso da Água: Simulação de um Caso. (Alternatives for Granting and Charging for Water Use: Simulation of a Case.) Porto 
Alegre: IPH/URGS, 2000. p 200. PhD thesis Programa de PósGraduação em Engenharia de Recursos Hídricos e Saneamento Ambiental do IPH/UFRGS. Universidade Federal do Rio Grande do Sul, Porto Alegre, RS

Ribeiro MM, Lanna AE (2003) A outorga Integrada das Vazões de Captação e Diluição. (The Integrated Grant of Capitation and Dilution Flows.) In: Revista Brasileira de Recursos Hídricos 8(3):151-168

Setti AA, Lima J, EFW, Chaves AGM, Pereira IC (2001) Introdução ao Gerenciamento de Recursos Hídricos. (Introduction to Water Resources Management), $2^{\mathrm{a}}$ ed. ANEEL, Brasília

Silva AM, Oliveira PM, Mello CR, Pierangeli C (2006) Vazões mínimas e de referência para outorga na região do Alto Rio Grande, Minas Gerais. (Minimum and reference flows for granting in the Alto Rio Grande region, Minas Gerais). RBEA 10(2):374-380
Tucci CEM (2002) Regionalização de vazões. (Regionalization of flow rates). Ed. Universidade/UFRGS, p 256

Vergara FE, dos Reis FC, Magalhães Filho LNL, Rezende CSA (2013) Proposta de Vazão de Referência Q90 para o Rio Formoso na bacia do Araguaia. (Proposal for a reference flow Q90 for Formoso river in Araguaia Basin). Environmental Engineering_Espírito Santo do Pinhal 10(1):84-102

von Sperling M (2007) Estudos e Modelagem da qualidade da água de rios. (Studies and Modeling of water quality of rivers). Belo Horizonte: Editora UFMG 7:588

\section{Publisher's Note}

Springer Nature remains neutral with regard to jurisdictional claims in published maps and institutional affiliations. 